\title{
Wallander's Dark Geopolitics
}

\author{
Jakob Stougaard-Nielsen
}

School of European Languages, Culture and Society, University College London, UK

\begin{abstract}
A current fault line in the study of crime fiction as a transnational genre is to what extent crime novels offer readers genuine cosmopolitan windows onto other worlds and cultures or whether it simply is bound to reproduce trite imagologies and national stereotypes. The overarching premise for this article is to explore the extent to which Henning Mankell's crime novels and their adaptations engage the character Wallander's own and "other" worlds with a cosmopolitan perspective, by considering the mutations of Wallander's fictional local world as intricately tied to discursive geopolitical realities of the post-Cold War world. More specifically, I consider what may be gained from exploring the Wallander series within two distinct - yet, I shall argue, related - perspectives on geopolitics and crime fiction: on the one hand, the geopolitics of the translation, adaptation, and reception networks that have "worlded" the Wallander series (what I call Wallander's geopolitical adaptation networks), and on the other, the fictional geopolitical networks that weave the Global North and the Global South together in several of Mankell's intricate crime plots (Wallander's dark geopolitics).
\end{abstract}

Keywords: Nordic Noir, geopolitics, translation, adaptation, Wallander

\section{Introduction}

Internationally, Henning Mankell's series of crime novels (1991-2009) featuring the police inspector Kurt Wallander has arguably become the seminal representative of not only Scandinavian crime fiction, but also of non-anglophone crime writing in translation more generally. Having been translated from a relatively small European language into around 40 languages, and selling more than 40 million copies worldwide, in the US and UK Mankell surprisingly became, according to Barry Forshaw (2012: 21), "the market leader" and "the standard bearer for foreign crime in translation". Mankell's Wallander series and its televisual adaptations are - at least outside of the Scandinavian countries - considered seminal representatives of a regional subgenre of international crime fiction. Particularly the two Swedish and one British televisual adaptations are considered pivotal to the formation of the Nordic Noir brand, with its gloomy, Nordic locations, melancholic detectives, and critical portrayals of deteriorating social mores in the Scandinavian welfare states, perceived to be in perpetual decline.

Stougaard-Nielsen, J. (2020). Wallander's dark geopolitics. Nordicom Review, 41(Special Issue 1), 29-42. https://doi.org/10.2478/nor-2020-0014 
The rise of Scandinavian crime fiction from the late 1960s to the first decades of the twenty-first century is intimately tied to a widespread anxiety about disruptions of familiar social imaginaries associated with the late-modern welfare society (StougaardNielsen, 2017). Such local disruptions must, particularly in this period, be considered within a wider transnational and geopolitical field of interrelations and tensions. Arguably, Mankell's ability to refract Wallander's small, local world and an emerging hyperconnected global world has been central to his enduring transnational success.

As an influential example of Nordic Noir, Mankell's Wallander series offers not only entertaining crime plots conforming to international expectations and tastes - a local form within which global uncertainties are refracted - but also, significantly, localised Swedish narratives that seem to appeal to a global audience's taste for new "destinations" in bestseller and international television markets saturated with anglophone crime narratives. As I have argued elsewhere, the international success and transmission of contemporary crime narratives goes hand in hand with the exploitation of exotic, peripheral locations, such as the Nordic (Stougaard-Nielsen, 2016). Similarly, Anderson and colleagues (2012: 3) have argued that the current globalisation of crime fiction demonstrates that it trades in "exotic environments", which bring the genre "into close proximity to travel writing", revealing a genuine interest in other cultures or, perhaps, a less cosmopolitan "desire for a kind of cultural Disneyland".

A current fault line in the study of crime fiction as a transnational and transmedial genre, therefore, is to what extent crime novels and television series offer readers genuine cosmopolitan reflections of other worlds and cultures or whether they are simply bound to reproduce trite imagologies and national stereotypes. The overarching premise for this article is to explore the extent to which Mankell's crime novels and their adaptations engage the character Wallander's own and "other" worlds with a cosmopolitan perspective, by considering the mutations of Wallander's fictional local world as intricately tied to discursive geopolitical realities of the post-Cold War world. More specifically, I consider what may be gained from exploring the Wallander series within two distinct - yet, I shall argue, related - perspectives on geopolitics and crime fiction, or Nordic Noir: on the one hand, the geopolitics of the translation, adaptation, and reception networks that have "worlded" the Wallander series (what I call Wallander's geopolitical adaptation networks), and on the other, the fictional geopolitical networks that weave the Global North and the Global South together in several of Mankell's intricate crime plots (Wallander's dark geopolitics).

I begin with a discussion of the geopolitical issues that arise with the English translation of Mankell's Mördare utan ansikte [Faceless Killers] (1997), wherein "foreignness" is tied to both the issue of national borders, immigration, race, and racism in the novel's diegesis and a question about the geopolitics of translation. Around these issues have arisen considerable debate in the reception of Mankell's series, where some critics judge the Wallander novels to be fundamentally reactionary and reproducing a xenophobic worldview the author himself purports to critique (Tapper, 2014; Pepper, 2013), while others consider his novels more ambiguous and cosmopolitan in their dealing with global inequalities and race (Nestingen, 2008).

From this debate, I move on to discuss what I call Wallander's dark geopolitics as most clearly expressed in the post-apartheid novel Den vita lejoninnan [The White Lioness] (2012). With the notion of dark geopolitics, I point to the crime novel's treatment 
of sociopolitical inequalities and historical fissures between the Global North and the Global South, into which Wallander, more or less accidentally, finds himself inserted. While this third of Mankell's Wallander novels emphatically engages with bordercrossing crimes, global politics, racism, and the fate of the late-modern Swedish welfare state, surprisingly few critics have discussed this novel in relation to Mankell's selfdeclared ambition - as explained in the foreword to The Pyramid - to critically assess the social and political transformations unfolding in his contemporary Sweden, using the crime genre to produce a series of "variations on a single theme: 'What is happening to the Swedish welfare state in the 1990s? How will democracy survive if the foundation of the welfare state is no longer intact?" (Mankell, 2009: 1). Mankell considered his series of Wallander novels an investigation into "the Swedish anxiety" about race and racism - which he encountered upon his return to Sweden from extended stays in mostly Zambia and Mozambique around 1989 - and he decided to use his protagonist "as a kind of mouthpiece for growing insecurity, anger and healthy insights about the relationship between the welfare state and democracy" (2009: 1). Clearly, Mankell himself considered his crime novel an ideological tool, and one that enabled a transnational exploration of race and democracy across seemingly very different societies and geographies.

The final part of my discussion returns to the question of how the Wallander novels have become worlded through adaptation networks, with examples drawn from the Swedish and British adaptations of The White Lioness, the latter of which transposes Mankell's narrative to a contemporary South Africa. With these examples, I want to explore not only what the Wallander series may tell us about a Swedish or Scandinavian perspective on the dark geopolitics of their time, but also how a British television adaptation two decades later repurposed Mankell's geopolitics for a new context.

\section{Wallander's geopolitical adaptation networks I: Translation}

According to Hansen and colleagues (2018: 11), the transnational impact of Nordic Noir "suggests that its locative implications has turned into a set of identifiable stylistic and narrative tropes that, as a result, extends beyond the Nordic region". In a globalised age, Nordic Noir demonstrates that crime fiction is a principally mobile and adaptable genre able to spread and take root throughout the world by adapting internationally recognisable literary and audiovisual forms to local circumstances, languages, and traditions (Stougaard-Nielsen, 2016). This confluence of transnational form with local specificity makes crime fiction a preeminent case for exploring popular discursive constructions of geopolitical imaginaries across national borders through translations and adaptations.

Translation and adaptation studies have more recently adjusted to the complexities of cultural transfers in a globalising world by not merely considering translation and adaptation as one-way transfers of text from one language to another, or as studies mostly concerned with film adaptations of literary works. As Bruhn and colleagues (2013: 8) describe the current field of adaptation studies, "adaptation is viewed within a more comprehensive understanding of the cultural and textual networks into which any textual phenomena is understood". Mankell's Wallander series and its many translated and adapted instantiations could therefore productively be considered within what Kate Newell has defined as "expanding adaptation networks", which together make up the transnational and multimodal work and transcultural phenomenon of the series (2017: 
26). In this article, I consider instantiations of Mankell's series to be enmeshed in such cross-cultural networks of worlding and world-making, constituting something akin to a dark textual and popular geopolitical ecology, to adapt a phrase coined by Timothy Morton (2016). Such networks are not without contestations and friction. Particularly with the issue of translation - where languages and cultures meet, clash, and grapple with each other in textual and social contact zones (Pratt, 2008) - do wider geopolitical issues of linguistic difference, cultural appropriation, and the production of foreignness congeal, demonstrating Robert A. Saunders's assertion that "popular culture is a force majeure in reifying, reinforcing, and rarefying politico-behavioural codes that stem from geopolitical visions of "fictive Wes and Thems"' (2019: 698). A geopolitical perspective on the adaptation and translation networks of crime fiction would gravitate towards an exploration of the rarefying, rather than reinforcing, worldviews that germinate from locally situated discourses on Others. This, because considering a text an already worlded network of instantiations necessarily complicates solid or unambiguous conceptions of local anchoring, originality versus derivative, domestic versus foreign.

Against this view on translation as participating in a non-hierarchical network of textual instantiations, particularly when it comes to popular genres, we find Lawrence Venuti's discussion of Mankell's international success in the revised second edition of his seminal work on translation theory, The Translator's Invisibility. Venuti (2008: 154) asks "whether the foreignness of the crime fiction is part of its attraction - or indeed whether any linguistic and cultural differences survive the translation and editing process". He concludes that anglophone readers are only attracted to foreign crime fiction in translation because it provides readers with a "homely" discursive form that reinforces already-held worldviews. Venuti's scepticism towards the ability of translated crime fiction to give readers access to foreign cultures pertains, therefore, largely to its generic form - a form that provides a false sense of familiarity with essentially unfamiliar "values, beliefs, and social representations that are fundamentally ideological, affiliated with the interests of individuals, groups, and institutions in [the foreign] culture" (Venuti, 2008: 155). Mankell's Wallander series is a case in point. Situated in Sweden, it has been translated and read by readers elsewhere who would likely be unfamiliar with the series" "original" sociocultural context. The result will inevitably be that a "sense of Swedishness" is "reduced to place names and descriptions as well as the proper names chosen for characters" (Venuti 2008: 155), inevitably resulting in banal transnationalism.

A crucial "ideological" difference relates to Wallander's ambiguous xenophobia most explicitly presented in the first novel of the series, Faceless Killers. The novel begins with the double murder of an old couple in their farm house outside of Ystad. The woman, however, turns out to still be alive. Her deathbed testimony, which describes the perpetrator as "foreign", makes Wallander fearful of what will happen if it becomes publicly known that the killers are "foreigners" - refugee camps in the area had already been attacked (Mankell, 1997: 44). While most of the crime investigation sees the police following false leads and having to deal with associated hate crimes and a dysfunctional immigration system, the killers do in the end turn out to be foreigners, though perhaps not visibly so, as they are two fair-skinned Czech criminals. The killers are, then, foreigners, and may be seen to endorse Wallander's and the public's fear of border-crossing Eastern European criminal gangs. As a "foreign" reader will be unfamiliar with the sociocultural context of Sweden in the early 1990s, Mankell's employment of 
the universal and familiar theme of racism "to generate suspense", according to Venuti, "provokes and thereby reinforces the reader's anxiety about immigrant crime even as it seeks to question the ethnic stereotyping on which that anxiety rests" (2008: 156).

Venuti's treatment of translations of Mankell, however, rests on the questionable assumption of homogeneous readerships of both source and destination cultures, of the irreconcilable difference between "original" and "foreign" readers, and particularly the assumption that the ideological content and the "original" sociocultural context of Mankell's novels were immediately and transparently accessible to Swedish readers. Rebecca Walkowitz (2015: 173) has criticised Venuti's call for more visible or "foreignizing" translations for confirming ingrained assumptions about such "original cultures", "invoking confidently the boundaries between insiders and outsiders". In fact, Faceless Killers is, at its core, a novel where the identification of what counts as foreign and domestic, outsiders and insiders, is charged with ambiguity - where identity, as already suggested in the title's "faceless" killers, is obscured, leaving readers with an open question about what unequivocally counts as Swedish. If there is such a figure as the "original Swedish reader", Mankell's novel addresses this disparate group: a group divided between different national and geopolitical worldviews.

Mankell's portrayal of Wallander as a Swedish "everyman" anxious about his increasingly unrecognisable country, makes the detective a reflector for a wider national confusion about morality and solidarity in the multicultural society. It is, therefore, tempting for Venuti, but also for the Swedish critic Michael Tapper, to read the Wallander novels as reproducing xenophobic prejudices through narratives that constantly depict crime and violence as something that arrives in an idyllic and innocent Sweden from the outside, "as in the old colonial detective stories" where crime is something foreign, "not really in our blood, not really in our culture, but something by which we have been contaminated" (Tapper, 2014: 170). However, as other critics have pointed out, "Swedishness" and "foreignness" - the inside and the outside - are presented as ambivalent figures in the Wallander series (Stenport, 2007: 3; Nestingen, 2008: 244).

In Faceless Killers, this ambivalence is already suggested when the investigative team are debating what the old woman could have meant by the word "foreign". Wallander's mentor Rydberg suggests: "Maybe they looked un-Swedish. Maybe they spoke a foreign language'. [...] 'What does an "un-Swedish" person look like?'” asked Wallander" (Mankell, 1997: 43). When the detectives finally hone in on the two Czech opportunists, wanting their real names, the police instead "translate" their ambiguous foreignness into domestic nicknames: Skallmannen [Skinhead] and Lucia (one has a shaved head and the other long fair hair). While the double-coding of skinhead is clear (pointing simultaneously to the criminal's foreignness and a stereotype of a home-grown racist), the name Lucia can also be read as a figurative contradiction, since the name refers to a popular national custom deeply ingrained in "Swedishness" and "whiteness". The foreign criminals are thereby labelled "as iconic representatives of Swedish culture, but in culturally conflicting ways" (Stenport, 2007: 13), which constitutes the novel's central open-ended exploration of how to determine what is understood as foreign to Swedish readers: people arriving from abroad or domestic widespread racism?

The double-coding of the foreign criminals by the police allows for at least two readings of the representation of immigration and Swedish racism in the novel: one that sympathises with a Swedish anxiety about the porous borders of a globalising world 
(which necessarily takes Wallander's anxieties as the novel's ethos), and one that insists on the novel's ambivalent presentation of the killers' foreignness and Wallander's own xenophobia. The latter reading suggests that Mankell intended his readers to explore how emerging xenophobic fears are turning a famously progressive solidaristic and humanitarian nation into a peripheral, anxiety-ridden anachronism.

However, both a domestic and a foreign reader will have to face this ambivalence, mainly due to the contradictory anxieties embodied in the figure of Wallander himself who, with his reactionary views and racist inclinations, becomes an uncomfortable protagonist with whom the reader is challenged to identify. In Faceless Killers, we are introduced to Wallander's racism through his erotic dreams of a faceless black woman. These recurring psychopolitical dreams form a narrative frame of the novel, as if embedding the otherwise social-realistic narrative within an overdetermined colonial fantasy of the subjugation of the feminised and exoticised Other:

When the telephone roused him, he was deep in an intense, erotic dream [... and] he was alone in the bed. Neither his wife, who had left him three months ago, nor the black woman with whom he had just been making fierce love in his dream, was there. (Mankell, 1997: 7)

Rather than referring Wallander's racism to the overall ethos of the novel, as Tapper does, it is an essential aspect of the narrative, according to Nestingen (2008: 249-250), that Mankell "goes out of his way to impute to Wallander antisocial and racist attitudes [...]. In depicting a discomforting and reactionary anger in Wallander's questions and attitudes, the novels provoke the reader to disagree with the complex Wallander". The result is a police novel, featuring an ambiguous representative of the state, which centrally questions the state of individual and Swedish humanitarianism in a globalising world.

Mankell's crime novel is reflexive about the geopolitical watershed moment in which Wallander finds himself in the early 1990s: the worlding of his "small Sweden" necessitates a reevaluation or estrangement of what counts as domestic and foreign. Rather than a device that precludes access to "the foreign", as argued by Venuti, Mankell redeploys the transnationally familiar police procedural to rarefy, not reinforce, locally anchored "geopolitical visions of 'fictive Wes and Thems"” (Saunders, 2019: 698).

\section{Wallander's dark geopolitics: The White Lioness}

Slavoj Žižek suggests that the significance of Mankell's police procedural is that it is a "perfect illustration of the fate of the detective novel in the era of global capitalism" (2003: 24). The Wallander series illustrates how the crime novel's setting has become bounded by "the specific locale, a particular provincial environment" as a "dialectical counterpart" to the globalised world, where, Žižek concludes, "a detective story can take place almost anywhere" (2003: 24). However, what makes Mankell's police procedural a good example of the geopolitical potential of the crime novel is not merely its rootedness in a "provincial environment"; it is, perhaps more importantly, the always present and uneasy attachments of Wallander and his affluent Sweden to global Others and elsewheres, as suggested by the fact that several of the novels' brief prologues are set in the Global South before the action moves to Ystad. 
Rather than suggesting that the senseless violence and the general denigration of morals in the Swedish welfare state are caused by outside forces, I want to suggest that Mankell employs Swedish and foreign localities as windows into disparate locations that, as Žižek suggests, "stand for different aspects of the same constellation" (2003: 24). In fact, Žižek insists that where there might be echoes of each locality in its opposite, "the effect is an insistence on the irreparable split in the global constellation" (2003: 24). To Žižek, Mankell's most important insight is that the two worlds will necessarily remain separated - no translation is possible between the two in an age of globalised capitalism. Therefore, Žižek does not care much for those Wallander novels where Mankell has sent his detective out of Ystad or where the plot is divided more equally between home and abroad.

However, it is precisely in The White Lioness, set partly in South Africa, that we may see how this Swedish crime novel is more deeply entangled with geographical and cultural Others; it is not a novel that demonstrates the inevitable "untranslatability" between the North and South, but one that actively engages in closing the gap between the "here" and "there" - the domestic and the foreign - to reinforce a solidaristic Swedish internationalist self-image. With The White Lioness, Wallander becomes, in the words of Tapper (2014: 171), "a small time cop in a drama of world politics", as he hunts and is being hunted by the cold-blooded former KGB agent, Konovalenko. The Russian mercenary is working for a racist, secretive Boer Committee, tasked with training a black South African to assassinate - without knowing the exact target - Nelson Mandela. Set in the early post-apartheid years, the novel's dramatisation of disparate worlds and the struggle to build a new South Africa inevitably affect even the "small" world of the Swedish cop.

As noted by Mankell in the epilogue, The White Lioness was written "almost a year before the first free elections in South Africa: April 27, 1994" (2012: 564). It was published three years after the release of Nelson Mandela from Robben Island in 1990, as Mankell notes in the prologue, and published the year President de Klerk and Mandela were jointly awarded the Nobel Peace Prize in Oslo. ${ }^{1}$ As such, the novel, which also became Mankell's international breakthrough, appeared at the height of international attention to the political transformation of South Africa. Bookended with the author's notes about the vulnerable political transition of a country far from the homely haunts of Wallander's Ystad, this “foreign" world frames the novel's initial local investigation into the confusing murder of an estate agent in the Scanian countryside - an exposition not dissimilar to the opening of Faceless Killers. Here, however, the vague whisper of the involvement of "foreigners" is replaced by clues found at the crime scene: a black man's finger, remnants of advanced radio equipment, and a gun, pointing to Russian and South African origins.

On the surface, it appears once again that Wallander's Swedish idyll has been disturbed by the threatening presence of foreigners, illustrating - as the synopsis on the back of the first British edition of The White Lioness (translation first published in 1998) clarifies - "an increasingly globalised world in which international terrorism knows no borders". Mankell appears to pit Swedes against threatening Others to shore up a nostalgic vision of an ethnically homogeneous Sweden. This, according to Saunders, is one way in which popular genres may participate in producing "stable geopolitical visions that inform one polity's ideas about other polities", how collective identities are shaped through repetitive discursive renderings of insecurity and disadvantage in relation to 
others (2019: 698). However, while Wallander still despairs about "What's going on in the country of ours?" (Mankell, 2012: 39), the colonial sexual phantasies that framed Faceless Killers are, in The White Lioness, replaced by a dream that connects him to the Zulu South African contract killer cum victim, Victor Mabasha, who Konovalenko first dismembered then executed - a fate that a depressed and melancholic Wallander, towards the end of the novel, blames on himself:

At dawn, just before he woke up, Wallander had a dream that one of his hands was black. He had not put on a black glove. It was his skin that had grown darker until his hand was like an African's. In his dream Wallander wavered between reactions of horror and satisfaction. Rydberg, his former colleague who had been dead for nearly two years, looked disapprovingly at the hand. He asked Wallander why only one of them was black. "Something will have to happen tomorrow as well," Wallander said in his dream. When he woke up and recalled the dream, he lay in bed wondering about the reply he gave Rydberg. What did he mean by that? (Mankell, 2012: 102)

It is, indeed, not entirely clear what this dream suggests. Perhaps it points to a troubled future through the contradictory affects embodied in Wallander's perception of blackness, and a Manichean depiction of "us" and "them", white and black, as unbridgeable opposites. Read more sympathetically, Wallander's dream of having one white and one black hand may be a premonition of his growing sympathy for Mabasha's plight (his black hand referring to Mabasha's severed finger) and his failed attempt to smuggle him out of Sweden. Interpreted in this way, the dream constitutes a psychopolitical reverberation in Wallander of the explosive black-white relations that are being played out in the South African parallel narrative, where the assistant to the chief prosecutor in Johannesburg, Wallander's white South African double Georg Scheepers, is charged with investigating the Boer Committee's conspiracy to assassinate Mandela. Wallander's ambiguous embodiment of black and white skin is, of course, a rather crude symbolic reference to the struggle between a new, more egalitarian South Africa and white racist forces bent on returning the country to racial segregation and apartheid. The psychopolitical significance of dreams is a recurring feature in Mankell's crime novels, and in The White Lioness the protagonists' dreams connect the global constellation of Sweden and South Africa, which otherwise only "physically" link through delayed telecommunications and border-crossing contract killers.

Wallander's dream in The White Lioness has its mirror image in Scheepers's recurring visions of the eponymous white lioness. He first observes the lioness in the moonlight at Kruger national park with a sense of "horror" and attraction. As ambivalent and vague as Wallander's dream of his black hand, Scheepers senses that the lioness is a reminder of something he has forgotten (360); perhaps a feeling of imminent danger, which also characterised the state of his country, "a symbol of Africa" (491). Finally, with more clarity, he realises what the white lioness had meant to him all along, as recorded in the interior monologue of the novel's last lines: "That first and foremost he was not an Afrikaner, a white man. He was an African" (563). The psychopolitics that connects Wallander's sense of personal and national guilt towards the "foreigner" Mabasha and Scheepers's embodiment of the racial and political transition of South Africa marks out the narrative's dark geopolitics, which point towards the need to restore a Swedish 
self-image of activist internationalism built on solidarity with distant Others. Following Saunders, I argue that Mankell's novel is "delimitating the 'foreign', building new worlds, and making sense of geopolitical conflict and cooperation", in order to use the popular genre of crime fiction to engage in an "ongoing national-identity building" project, which is closely related to the wellbeing of others (Saunders, 2019: 699).

While Sweden may be a peripheral country in world politics, it was and still is a comparatively influential nation due to its generous foreign aid, particularly to countries in Africa - the opposition to the apartheid regime in South Africa is testament to this, as is the fact that Sweden was the first country Mandela travelled to - in order to visit the exiled Oliver Tambo in the hospital - outside of Africa upon his release from prison. During apartheid, Sweden held a significant critical stance against the regime, supporting an international boycott and the African National Congress in their struggle for political change. However outlandish the plot of The White Lioness may appear, it must be seen within the geopolitical context of its day and in relation to a, perhaps somewhat mythical, Swedish self-perception as a global humanitarian superpower: a self-image wherein a "small nation" (embodied in a "small time cop") perceives its local egalitarian welfare state as entangled with the plight of global Others $^{2}$. As an increasingly affluent sovereign and neutral state in the post-World War II period, Sweden built a modern, universal welfare state, whose understanding of solidarity and equality did not extend exclusively to Swedes within its Social Democratic folkhem [people's home]. Most famously, Prime Minister Olof Palme (1969-1976, 1982-1986) played a central role in developing an extensive foreign aid programme and promoting internationalism and solidarity which "acquired a status of national ideology" (Trägårdh, 2002: 152). This, according to Annika Bergman (2007: 74), became expressed in "Sweden's self-narrative [...] of an outward-looking internationalist state whose commitments to justice and equality are not confined to co-nationals". Critical voices, including Mankell's, have decried the gradual corruption of this national ideology since the early 1990s, made visible by right-wing populism and growing opposition to immigration.

One important link between the vulnerable transition of South Africa and Swedish internationalism is the national trauma of Palme's, until very recently, unsolved murder in 1986. Being a famously outspoken anti-apartheid advocate, a theory has regularly surfaced of the involvement of vengeful supporters of apartheid in his murder. Eugene de Kock (codename Prime Evil) was a convicted leader of an apartheid-era hit squad, who testified that Palme was assassinated by a secret unit tasked with subverting and silencing apartheid critics overseas supported by Swedish extreme-right forces - a group that also turns out to have harboured Konovalenko in Mankell's novel. The entangled history of Sweden's modern welfare state, anxieties about its decline, and the dissolution of apartheid in South Africa is the dark geopolitical ecology from which Mankell draws the plot and humanitarian ethos in The White Lioness. This ethos nostalgically calls for a cosmopolitan, activist state, however mythical - one that conceives of its duty beyond borders or the dictates of state sovereignity (Bergman, 2007). By constructing a geopolitical constellation through two parallel crime plots (Wallander's ambiguous reaction to social change in his homely yet defamiliarised welfare state mirrored in Scheepers's equally ambiguous vision of the need to revise his own sense of racial and national identity in a transforming South Africa), Mankell asks the reader to recognise 
one (oneself) empathetically in the other, in line with a national welfare ideology of cross-border solidarity. Rather than confirming an inevitably split and untranslatable world order, at least part of the Wallander series' global appeal may relate to Mankell's challenge to his readers: to empathise with the ambiguous Wallander as he struggles to maintain his own solidaristic entanglement with distant Others in an age of deepening geopolitical conflicts and global inequalities.

\section{Wallander's geopolitical adaptation networks II: Adaptation}

Screened on BBC One in May 2016, with a viewership of more than five million, the British adaptation of The White Lioness (Dormer \& Caron, 2016), featuring Kenneth Branagh as Kurt Wallander, coincided with a peak in what was popularly referred to in European media as the migrant or refugee crisis. An unprecedented increase in asylum seekers from the Middle East and Africa, fleeing war, oppression, and destitution, sought safe haven in Europe where public opinion, and EU and national governments, gradually turned away from more open immigration policies to focus almost entirely on how best to secure the borders of Fortress Europe. In January 2016, The Guardian newspaper in the UK reported that having received the highest proportion of asylum seekers compared to the size of its population, the Swedish government "now considers that the current situation [...] poses a serious threat to public order and national security", following which legislation was reluctantly put in place enabling further border controls meant to dissuade future migrants from traveling to Sweden - a drastic departure from previous policies (Crouch, 2016). Though still a country doing more than its fair share of international development and aid, the Swedish image as a humanitarian superpower was being tainted and revised in popular opinion at the time Mankell's narrative about the need for international solidarity with distant Others was adapted for a British television audience.

Twenty years previously, the Swedish adaptation (Bengtsson et al., 1996) featuring Rolf Lassgård as Wallander had been fairly faithful to the novel. However, it did strengthen the national geopolitical discourse by overemphasising the role of Sweden in the dissolution of the apartheid regime, highlighting the Palme inquiry that remains under the surface in the novel, and by relocating the final scene of the assassination attempt to Oslo during the Nobel Prize ceremony for Mandela and de Klerk. Where Wallander only in the last moment succeeds in sending a fateful telex to the investigators in South Africa in the novel, enabling them to identify and capture the assassin, in the Swedish adaptation it is Wallander himself who saves the day, spoiling the aspirations of the white Boer Committee to return to the dictatorial rule of a white minority. Similarly, in the novel, the white lioness embodies the internally motivated transition of white South Africa into the promised African rainbow nation, whereas in the adaptation the lioness symbolises a doomed white South Africa succumbing to the pressures of outside forces - an adaptation that testifies to the function of national public television productions in consolidating a sense of collective identity through the reification of national geopolitical self-images.

The BBC Wallander adds a further node to the adaptation network within which Mankell's original novel and its situated "ideological" context is given new life and meanings. It does so by subverting Venuti's claim of untranslatability between the 
original and the derived through reproducing the original's ideology of international solidarity, albeit as seen through a foreign gaze. Anne Marit Waade (2011: 58) convincingly argues that the $\mathrm{BBC}$ Wallander series is engaged in constructing a certain kind of touristic "Swedishness":

"Swedishness" is constructed from a British point of view, which creates a nostalgic and picturesque image of Swedish culture and rural landscapes that also includes a construction of Britishness as something different from Swedishness. In other words, the settings and landscapes of TV series are used to ensure realism, recognition and familiarity, and at the same time to create estrangement (with a touristic view of Scandinavian landscape and culture) and aesthetification (emphasising the picturesque).

This particular dynamic of geopolitical adaptation - where the foreign is culturally appropriated and made recognisable and homely - was also found in Venuti's critique of the ability of translated crime novels to engage cosmopolitan perspectives. It appears that adaptations and translations fare equally poorly in providing more than superficial impressions of the foreign text and culture.

Granted, the BBC Wallander series does explicitly trade in a wide range of national stereotypes - and knowingly so - where Sweden nostalgically represents national welfarist values considered lost to a British self-image. However, I argue that with the adaptation of The White Lioness - taking into account the "ideological" context in which it appeared - its overdetermined narrative of a Swedish internationalist self-image reified on foreign soil in a South African landscape presented itself to British viewers not as an unproblematic touristic image of Swedishness, but as an uncomfortable mirror image of British colonial nostalgia in the midst of a "refugee crisis" that implicated Britain as much as Sweden.

Doing away with the parallel constellation of a North-South divide, the BBC adaptation takes place entirely in South Africa, where Wallander is attending a police conference, decades after the first free elections, and is struggling to prepare a speech about how he sees the police "making a difference". The keynote speaker at the conference is the South African tourism minister, a former African National Congress partisan imprisoned with Mandela, who delivers a talk about the importance of security to the development of the tourism industry. When a Swedish woman living in South Africa disappears and her husband complains that the local police are doing nothing to find her, Wallander is asked to try to persuade the husband not to obstruct the ongoing investigation. He is accompanied by the black female officer Grace Mthembu, who leads the investigation. Bored with the conference, Wallander, of course, cannot resist involving himself in the case, even if it means meddling in an investigation where he has no jurisdiction and no real local knowledge or sensibilities. Yet, it is paradoxically his behaviour as a tourist his wrong turns and being in the wrong places - that accidentally (and, some would say, implausibly) help move the investigation along the track mostly laid out in Mankell's novel but adjusted to a new local situation and historical context.

The target of the assassination plot in the adaptation is a young African National Congress politician, whose election campaign speaks out against building luxury hotels instead of providing housing for local communities. This new plot speaks directly to the local context in the 2010s: continuing inequalities and racial segregation in post- 
apartheid South Africa. The plot centrally involves, as Wallander and Mthembu will eventually discover, the corruption of the tourism minister Max Khulu, who is financially involved in the hotel construction. Having hired a contract killer to eliminate the young black politician, Khulu becomes a symbol of the fallen ideals of the new South Africa and the African National Congress in desperate need of hope and renewal.

Besides witnessing the uncomfortable effect of Wallander's unsolicited interferences that leave Mthembu constantly having to accept a white middle-aged foreign police officer taking over her investigation, the British viewer will also be confounded by Wallander's seemingly heartfelt promise to the hired contract killer Victor Mabasha, who abducted and threatened Wallander, to bring him to Sweden with the words: "Sweden is a good place. We try to help people who have been hurt". This message of idealised humanitarianism - which is, as I have argued, present (albeit nostalgically) in the original narrative as well - is further emphasised by yet another re-coding of the meaning of the white lioness. While the adaptation has maintained the original title, the lioness is in the diegesis re-gendered as a white lion to symbolise Wallander as a bringer of hope to South Africa - as pointed out by Mthembu and her daughter. No longer a narrative of solidaristic entanglements with distant Others, where social and personal change goes both ways, the BBC adaptation has Wallander, uncomfortably, acting as a neocoloniser, whose blatant disinterest in the foreign location and thwarting of local jurisdiction suggests that the South African police and, by extension, the state, are incapable of bringing change to their own country without the intervention of a Swedish, English-speaking "white lion".

The British adaptation may be seen to present Wallander's Sweden as an idealised humanitarian welfare state in need of being reinstated in an age where borders between the Global North and the Global South are being closed under the guise of protecting European national security. Such a cosmopolitan perspective exemplifies a cross-cultural elaboration on an idealised self-image already present in Wallander's novel. However, the adaptation also departs from Mankell's novel, not by presenting a touristic image of Swedishness, but by sending a British version of Wallander to a former colony with its well-known legacy of bloody wars and (as hinted at in the untranslated prologue of Mankell's novel) a source for the rise of nationalist Afrikaner identity and apartheid. As an interculturally illiterate tourist, the British Wallander does exhibit humanitarian sympathy with the plight of the African contract killer, but he simultaneously becomes an agent in colonial history as he disregards the sovereign nation's self-determination, becoming, in the end, a foreign beacon of hope figured in a foreign, male white lion - a figure uncomfortably charged with colonial nostalgia.

Again, the geopolitical constellation of what counts as domestic and foreign plays out ambiguously in the Wallander adaptation network. In the case of the British Wallander adaptation, it is inevitable that the cross-cultural detective (the British-Swedish Wallander), inserted into a "foreign" location with which the two nations share very different histories, will produce diverging narratives and local responses. The British cross-cultural adaptation might not elicit deeper insights into authentic Swedishness (if such exists); instead it uses the foreign source text as a mirror in which local viewers may see, at the same time desirable and uncomfortable, nostalgic self-images. 


\section{Conclusion}

My intention in the preceding discussion was to counter simplistic understandings of popular-cultural genres as necessarily incapable of providing more than superficial insights into foreign cultures. By exploring the negotiations of foreignness in the extended adaptation network of Mankell's Wallander series, I found multiple discursive constructions of geopolitical imaginaries that are situated yet interrelated, at times in conflict, but always responding to local values and social concerns as seen through encounters with a foreign language, geopolitical contexts, and self-images. Venuti's insight into the geopolitics of translation, particularly as it relates to culturally embedded notions of race and otherness - which will necessarily implicate the cross-cultural work of translation itself - alerts us to similar negotiations of otherness and translation already present in the source text. Therefore, as Mankell's text is mobilised through translation, it becomes clearer how a text like Faceless Killers mobilises its own generic foreignness to situate its readers in an estranged relationship with their own sociopolitical context. The British adaptation of The White Lioness is another node in the adaptation network that demonstrates the intercultural potential of Mankell's enmeshed, dark geopolitical crime novels. Going along with the source text's idealised humanitarian self-image, the crosscultural adaptation will inevitably be situated, by local viewers, in a radically different geopolitical context, where it becomes close to impossible to suspend the disbelief of Wallander's foreignness.

As a popular geopolitical form, it would be a mistake to consider crime fiction a discursive form that precludes access to "the foreign". As I hope to have at least suggested with the example of Wallander's adaptation network, this transnational and transmedial crime series asks us to question stale thinking of what constitutes domestic and foreign categories, and gives us access to discursive forms through which the fluidity of locally anchored "geopolitical visions of "fictive Wes and Thems"' (Saunders, 2019: 698) may have the widest impact on readers and viewers around the world.

\section{Notes}

1. In the Swedish edition, Mankell's prologue is a lengthy ten-page history lesson from which only four short paragraphs have been included in the English translation. Beginning in 1918 with the formation of the Afrikaner Broederbond, Mankell tells the story of the rise of Afrikaner nationalism following the Anglo-Boer Wars, and the secretive brotherhood that would come to play a central role in South African society and in the formation of apartheid. The prologue provides the crime story with a historical context for the secret Committee's plot to throw the country into a bloody civil war.

2. Mankell's life and authorship was deeply invested in creating connections between African countries and Sweden. Several of his writings take up African causes and he used part of the proceeds from his own publishing house Leopard Förlaget to promote African writers in translation. For many years until his death in 2015, he divided his time between Sweden and Mozambique, where he was artistic director of the Mutumbela Gogo Theater Company.

\section{References}

Anderson, J., Miranda, C., \& Pezzotti, B. (Eds.). (2012). The foreign in international crime fiction: Transcultural representations. London: Continuum.

Bengtsson, G., Faragó, K., \& Wight, D. (Producers), \& Berglund, P. (Director). (1996). Den vita lejoninnan [Television film]. Sweden: Sveriges Television AB-Sandrew Film AB.

Bergman, A. (2007). Co-constitution of domestic and international welfare obligations: The case of Sweden's social democratically inspired internationalism. Cooperation and Conflict, 42(1), 73-99. https://doi. org/10.1177/0010836707073477 
Bruhn, J., Gjelsvik, A., \& Frisvold Hanssen, E. (2013). "There and back again": New challenges and new directions in adaptation studies. In J. Bruhn, A. Gjelsvik, \& E. Frisvold Hanssen (Eds.), Adaptation studies: New challenges, new directions (pp. 1-16). London: Bloomsbury.

Crouch, D. (2016, January 4). Sweden and Denmark crack down on refugees at borders. The Guardian.

Dormer, J. (Writer), \& Caron, B. (Director). (2016). The white lioness [Television series episode]. In K. Branagh, R. Eaton, A. F. Fernandez, P. Harness, M. Read, \& A. Sjöberg (Executive producers), Wallander. London: Left Bank Pictures/Yellow Bird.

Forshaw, B. (2012). Death in a cold climate: A guide to Scandinavian crime fiction. Houndmills: Palgrave Macmillan.

Hansen, K. T., Peacock, S., \& Turnbull, S. (2018). Down these European mean streets: Contemporary issues in European television crime drama. In K. T. Hansen, S. Peacock, \& S. Turnbull (Eds.). European television crime drama and beyond (pp. 1-19). London: Palgrave Macmillan. https://www.doi.org/10.1007/9783-319-96887-2

Mankell, H. (1997). Faceless killers (S. T. Murray, Trans.). London: Vintage.

Mankell, H. (2009). The pyramid (E. Segerberg, \& L. Thompson, Trans.). London: Vintage.

Mankell, H. (2012). The white lioness (L. Thompson, Trans). London: Vintage.

Morton, T. (2016). Dark ecology: For a logic of future coexistence. New York: Columbia University Press.

Nestingen, A. (2008). Crime and fantasy in Scandinavia: Fiction, film, and social change. Seattle: University of Washington Press.

Newell, K. (2017). Expanding adaptation networks: From illustration to novelization. London: Palgrave Macmillan.

Pepper, A. (2013). Henning Mankell: Political reactionary. Moving Worlds, 13(1), 90-101.

Pratt, M. L. (2008). Imperial eyes: Travel writing and transculturation (2nd ed.). London: Routledge.

Saunders, R. A. (2019). Small screen IR: A tentative typology of geopolitical television. Geopolitics, 24(3), 691-727. https://doi.org/10.1080/14650045.2017.1389719

Stenport, A. (2007). Bodies under assault: Nation and immigration in Henning Mankell's "Faceless Killers". Scandinavian Studies, 79(1), 1-24. https://www.jstor.org/stable/40920725

Stougaard-Nielsen, J. (2016). Nordic Noir in the UK: The allure of accessible difference. Journal of Aesthetics and Culture 8(1), 1-11. https://doi.org/10.3402/jac.v8.32704

Stougaard-Nielsen, J. (2017). Scandinavian Crime Fiction. London: Bloomsbury.

Tapper, M. (2014). Swedish cops: From Sjöwall and Wahlöö to Stieg Larsson. Bristol: Intellect.

Trägårdh, L. (2002). Sweden and the EU: Welfare state nationalism and the spectre of Europe. In L. Hansen, \& O. Wæver (Eds.). European integration and national identity (pp. 130-181). London: Routledge.

Venuti, L. (2008). The translator's invisibility: A history of translation (2nd ed.). London: Routledge.

Waade, A. M. (2011). BBC's Wallander: Sweden seen through British eyes. Critical Studies in Television, 6(2), 47-60. https://doi.org/10.7227/CST.6.2.7

Walkowitz, R. L. (2015). Born translated: The contemporary novel in an age of world literature. New York: Columbia University Press.

Žižek, S. (2003). Parallax. London Review of Books, 25(22), 24.

Copyright: (C) 2020 The Author(s) and Nordicom. This is an Open Access article distributed under the terms of the Creative Commons Attribution 4.0 International License (CC BY-NC-ND 4.0). 